\title{
ANALISIS KINERJA KEUANGAN UMKM TENUN IKAT TROSO JEPARA
}

\author{
Hadi Ismanto \\ Universitas Islam Nahdlatul Ulama Jepara, Indonesia \\ Email: hadifeb@unisnu.ac.id
}

\begin{abstract}
Abstrak: Analisis Kinerja Keuangan UMKM Tenun Ikat Troso Jepara. Kontribusi UMKM terhadap PDB Indonesia sebesar 7\% dari total PDB pada tahun 2012. Salah satu faktor untuk meningkatkan kinerja keuangan yaitu dengan menginterpretasi perspektif yang ada dalam konsep balanced scorecard melalui kemampuan manajemen, strategi bisnis dan orientasi pasar. Populasi dalam penelitian ini adalah 314 pelaku usaha, teknik pengambilan sampel menggunakan purposive sampling sesuai kriteria UU No. 20 tahun 2008. Data penelitian dianalisis menggunakan analisis regresi berganda. Hasil penelitian menunjukkan bahwa faktor kemampuan manajemen, strategi bisnis dan orientasi pasar memiliki nilai koefisien determinasi $\left(R^{2}\right)$ sebesar $54,5 \%$ terhadap peningkatan kinerja keuangan. Secara parsial masingmasing variabel bebas memiliki pengaruh positif dan signifikan terhadap variabel terikat dalam penelitian ini.
\end{abstract}

Kata Kunci: Kemampuan Manajemen, Strategi Bisnis, Orientasi Pasar, Kinerja keuangan, UMKM

\begin{abstract}
Analysis of Financial Performance on UMKM Tenun Ikat Troso Jepara. Indonesian Small and Medium Enterprises give a contribution to GDP of $7 \%$ of total GDP in 2012. One factor to improve financial performance is to applicate some perspectives in the balanced scorecard concept through management capabilities, business strategy, and market orientation. The population in this study were 314 businesses, the sampling technique used purposive sampling with criteria that meet on UMKM's subject by the Law Number 20 of 2008. Data were analyzed using multiple regression analysis. The results show that the factor of management capabilities, business strategy and market orientation has the coefficient of determination of 54.5\% $\left(R^{2}\right)$ to the improvement of financial performance. In Partial each independent variable has a positive and significant impact on the dependent variable in this study.
\end{abstract}

Keywords: Management Capabilities, Business Strategy and Market Orientation, Financial Performance, Small and Medium Enterprises

\section{PENDAHULUAN}

Persaingan usaha yang semakin hari semakin tajam mengharuskan manajemen perusahaan memiliki nilai jual yang tinggi yang tidak pernah merasa lelah dalam merencanakan, mengorganisasikan, mengarahkan, dan mengendalikan sumberdaya organisasinya. Persaingan usaha yang membaik akan meningkatkan tingkat perekonomian Indonesia, pembangunan ekonomi melalui sektor Usaha Mikro, Kecil dan Mengengah (UMKM) menjadi salah satu sektor yang memberikan kontribusi terhadap Produk Domestik Bruto (PDB) sebesar 7\% dari total PDB tahun 2012 (Kementerian Koperasi dan UMKM RI, 2013). Kinerja Keuangan yang baik akan dapat meningkatkan pertumbuhan usaha. Usaha akan tumbuh dan berkembang tentu membutuhkan komponen-komponen yang 
saling mendukung dan peningkatan kinerja keuangan menjadi salah satu usaha untuk memperbaiki keuangan UMKM. Balanced scorecard merupakan salah satu tawaran untuk manajer dalam mengukur kinerja dengan estimasi keuangan dan non keuangan. Balanced scorecard menjadi pilihan untuk manajer yang baik agar meningkatkan pandangan mengenai visi misi dan strategi perusahaan untuk meraih keuntungan (Samryn, 2012).

Hal tersebut juga menjadi dasar penting dalam mempertahankan dan meningkatkan eksistensi UMKM Tenun Ikat Troso. Salah satu faktor untuk meningkatkan kinerja keuangan yaitu dengan menginterpretasi perspektif yang ada dalam konsep balanced scorecard melalui kemampuan manajemen, strategi bisnis dan orientasi pasar. Faktorfaktor tersebut yang akan dibahas dalam penelitian yang akan diteliti terhadap peningkatan kinerja keuangan pengusaha UMKM.

Kemampuan manajemen menjadi faktor yang penting dalam peningkatan kinerja keuangan perusahaan, karena manajemen yang menentukan ke mana arah perusahaan dan strategi apa yang akan dijalankan untuk mencapai tujuan perusahaan. Dalam mencapai tujuan perusahaan agar bisa efektif dan efisien diperlukan kemampuan 4 (empat) manajemen yang baik dan prinsipprinsip dalam bisnis. Seorang pemimpin seharusnya mampu menjalankan fungsifungsi utama manajemen dengan baik demi kelangsungan hidup bisnisnya dan untuk mencapai target perusahaan.

Faktor lain yang tidak kalah penting yaitu strategi bisnis. Strategi bisnis adalah kemampuan pengusaha dalam menganalisis lingkungan eksternal dan internal perusahaan, perumusan (formulasi) strategi, pelaksanaan rencana-rencana yang dirancang untuk mencapai tujuan perusahaan serta melakukan evaluasi atas strategi yang telah dilakukan untuk menyusun strategi baru yang akan digunakan pada periode yang akan datang. Faktor ini penting karena strategi yang dipilih akan menentukan besarnya tingkat pendapatan perusahaan melalui penjualan tiap periodenya, selanjutnya akan berpengaruh terhadap kinerja keuangan perusahaan yang dapat dilihat dari laba (profit) yang diperoleh.

Dalam kaitannya dengan kinerja keuangan perusahaan, orientasi pasar juga mempunyai peranannya. (Uncles 2000) mengartikan bahwa orientasi pasar sebagai suatu proses dan aktivitas yang berhubungan dengan penciptaan dan pemuasan pelanggan dengan cara terus menilai kebutuhan dan keinginan pelanggan. Kinerja perusahaan akan meningkat jika orientasi pasar dapat diterapkan dengan baik.

Kinerja adalah tingkat pencapaian atau prestasi dari perusahaan dalam periode waktu tertentu dengan tujuan agar perusahaan tetap berdiri atau eksis (survive), untuk memperoleh laba (benefit) dan perusahaan dapat berkembang (growth). Tujuan tersebut dapat tercapai apabila perusahaan tersebut mempunyai performa yang baik. Kinerja perusahaan dapat dilihat dari tingkat penjualan, tingkat keuntungan, pengembalian modal, tingkat turn over dan pangsa pasar yang diraihnya (Jauch \& Glueck, 1988).

Konsep balanced scorecard dengan mengemukakan tolok ukur keuangan saja tidak cukup memberikan informasi yang 
komprehensif untuk memandu perusahaan dalam rangka penciptaan nilai perusahaan dalam jangka panjang(Sinaga 2015).

Balanced scorecard digunakan untuk menyeimbangkan usaha dan perhatian eksekutif ke kinerja keuangan dan non keuangan, hasil studi tersebut menyimpulkan bahwa untuk mengukur kinerja eksekutif masa depan, diperlukan ukuran yang komprehensif yang mencakup empat perspektif yaitu keuangan, pelanggan, proses bisnis internal, dan pembelajaran dan pertumbuhan (Samryn, 2012).

Kemampuan manajemen merupakan seperangkat keterampilan teknis dalam melaksanakan tugas sebagai manajer untuk menggunakan sumber daya yang ada secara efisien dan efektif, sehingga kemampuan manajemen ini merupakan kemampuan untuk menggerakkan orang lain dalam menjalankan usahanya (Irawati, 2012).

Strategi bisnis adalah upaya untuk mengembangkan diri pada ceruk pasar yang diperoleh, dalam hal ini pengusaha UMKM dapat melanjutkan inovasi dan mendapatkan hasil yang alamiah didalam pasarnya. Pengusaha juga dapat mengembangkan potensinya melalui sumber daya manusia dan fasilitas yang ditawarkan kepada konsumen (Hunger \& Wheelen, 2003). Strategi bisnis ini berfokus pada peningkatan posisi bersaing produk dari perusahaan dalam suatu segmen pasar tertentu yang ditawarkan pengusaha (Hunger \& Wheelen, 2003).

Ada tiga jenis perspektif orientasi pasar diantaranya a) Orientasi pasar sebagai suatu perilaku; b) Orientasi Pasar sebagai sumber daya yang unik; dan c) Orientasi pasar sebagai kemampuan belajar (Silkoset \&
Ragnhild 2009). Perspektif konsumen yang digunakan pada variabel orientasi pasar dalam konsep balanced scorecard meliputi pengukuran kinerja yang berkaitan dengan penetapan segmen pasar dimana unit bisnis bersaing (Samryn, 2012). Orientasi pasar yang kuat dalam suatu perusahaan dapat memberikan penawaran dan kepuasan yang lebih kepada konsumen atau pelanggan dan akan membawa hasil penjualan yang besar untuk perusahaan (Adinoto 2013).

Kemampuan manajemen dalam mengelola usaha terutama dalam UMKM sangat diperlukan guna menentukan arah strategi pengembangan usaha bagi pemilik. UMKM yang selama ini identik dengan manajemen tradisional dengan berpusat pada pemilik.

Kemampuan manajemen di antaranya adalah kemampuan komunikasi, kemampuan mengatur waktu dan tekanan, kemampuan mengatur keputusan individu, kemampuan mengenali, menetapkan dan memecahkan permasalahan, kemampuan memotivasi dan mempengaruhi orang lain, kemampuan pendelegasian, kemampuan menentukan tujuan dan mengartikulasikan visi, kemampuan membangun tim dan kemampuan mengatur konflik memiliki peran yang penting dalam memajukan usaha (Suci 2009).

Efisiensi dan efektivitas dalam pekerjaan dapat dihasilkan dengan memiliki kemampuan manajemen yang baik sehingga berdampak pada peningkatan kinerja keuangan. Diduga variabel kemampuan manajemen mempunyai pengaruh yang signifikan terhadap peningkatan kinerja keuangan. H1: diduga kemampuan 
manajemen mempunyai pengaruh yang signifikan terhadap Kinerja Keuangan

Strategi bisnis didasarkan pada usaha memenuhi kebutuhan khususnya dari pelanggan, dengan lini produk yang sedikit. Semua itu untuk menghindar dari produk konsumen yang rawan terhadap perang iklan dan introduksi produk baru yang pesat.

Variabel strategi bisnis diduga mempunyai pengaruh yang signifikan terhadap peningkatan kinerja usaha, hal ini sesuai dengan penelitian (Shaferi \& Handayani 2013) yang mengemukakan keunggulan bersaing yang diterapkan oleh UMKM Kabupaten Banyumas didapat dengan menentukan strategi bisnis yang tepat bagi perusahaan sehingga dapat meningkatkan nilai perusahaan. Strategi bisnis direncanakan untuk mencapai biaya rendah dengan menciptakan produk yang unik untuk pelanggan yang diferensiasi (Pearce, 2007).

Untuk itu peneliti juga menyakini bahwa dengan penerapan strategi bisnis yang tepat maka UMKM dapat meningkatkan pendapatannya guna meningkatkan kinerja keuangan. H2: diduga strategi bisnis mempunyai pengaruh yang signifikan terhadap Kinerja Keuangan.

Orientasi pasar merupakan cara yang digunakan untuk mendapatkan dan mempertahankan keunggulan kompetitif yang dimulai dengan perencanaan dan koordinasi dengan semua bagian yang ada dalam organisasi untuk memuaskan kebutuhan dan keinginan pelanggan.

Untuk itu orientasi pasar harus menekankan pentingnya analisis kebutuhan dan keinginan target pasar secara lebih efisien dan efektif dibandingkan dengan pesaingnya dalam usaha untuk mencapai keunggulan bersaing. UMKM yang dapat mencapai keunggulan bersaing maka dengan sendirinya dapat meningkatkan pendapatan yang dicapai dengan kemampuan memenuhi kebutuhan pelanggan (Akhiri \& Diponegoro, 2016)

Penekanan orientasi pasar terhadap daya saing berdasarkan pada pengidentifikasian kebutuhan pelanggan sehingga setiap perusahaan dituntut untuk dapat menjawab kebutuhan yang diinginkan pelanggan baik itu melalui penciptaan produk yang baru atau pengembangan dari produk yang sudah ada, agar dapat menciptakan superior value bagi konsumennya secara berkelanjutan dan dapat menjadi modal utama bagi perusahaan untuk dapat memenangkan persaingan. H3: diduga orientasi pasar mempunyai pengaruh yang signifikan terhadap kinerja Keuangan.

\section{METODE}

Objek pengamatan dalam penelitian ini adalah pelaku UMKM tenun Troso dengan jumlah populasi sebanyak 314 pelaku usaha, dalam teknik sampel digunakan metode purposive berdasarkan kriteria UMKM UU Nomor 20mTahun 2008 dengan karakteristik jumlah tenaga kerja sebanyak 5-99 orang, nilai kekayaan bersih selain tanah dan gedung sebesar $\leq 500$ Juta, dan akumulasi penjualan selama 1 tahun sebesar $\leq 2,5$ Milyar

Adapun teknik analisis dari 100 sampel yang didapat dari karakteristik pemilihan sampel tersebut dilakukan uji instrumen menggunakan uji validitas dan reliabilitas. Kemudian dianalisa dengan model persamaan regresi linier berganda sebagai berikut: 
$Y=\alpha+\beta_{1} X_{1}+\beta_{2} X_{2}+\beta_{3} X_{3}+\varepsilon$

Keterangan:

$Y=$ Kinerja Keuangan

$\mathrm{X}_{1}=$ Kemampuan Manajemen

$\mathrm{X}_{2}=$ Strategi Bisnis

$\mathrm{X}_{3}=$ Orientasi Pasar

$\alpha=$ konstanta

$\beta=$ koefisien regresi

$\varepsilon=$ residual

\section{HASIL DAN PEMBAHASAN}

Uji validitas digunakan untuk mengukur sah atau valid dari jawaban suatu kuisioner dimana dalam penelitian ini menggunakan uji Confirmatory Factor Analysis (CFA) untuk mengkonfirmasi sebuah variabel. Asumsi yang mendasari hal ini perlu memiliki korelasi yang cukup antar variabel dengan melihat nilai KMO (Kaiser-Meyer-Olkin Measure of Sampling Adequancy) harus > 0,50 untuk data yang bisa dikatakan valid (Ghozali, 2013).

Hasil analisis menunjukkan bahwa nilai KMO sebesar 0,727 sehingga sudah melebihi nilai 0,50 dan nilai Barlett test dengan Chisquares $=1804,494$ dan signifikan pada 0,000 maka dapat disimpulkan bahwa uji analisis faktor dapat dilanjutkan. Hasil pengujian analisis faktor juga diperoleh nilai communality berkisar antara 0,511 dan 0,908 , serta loading factor semuanya di atas 0,4 . Dengan demikian instrumen yang dikembangkan dalam penelitian ini sudah memenuhi persyaratan validitas.

Selain menguji validitas data yang diperoleh, peneliti menguji reliabilitas menggunakan rumus Alpha Cronbach's. Dikatakan reliabel jika nilai Alpha Cronbach's lebih besar dari 0,60 (Ghozali, 2006). Hasil pengujian juga menunjukkan nilai Cronbach's Alpha yang ditemukan berkisar antara 0,653 - 0,854. Dengan demikian dapat disimpulkan bahwa instrumen yang dikembangkan sudah reliabel.

Hasil pengujian dengan menggunakan regresi liner berganda sebagaimana ditampilkan di Tabel 1, dapat diperoleh persamaan regresi berganda sebagai berikut: $Y=0.166 X_{1}+0.213 X_{2}+0.517 X_{3}+\varepsilon$

Berdasarkan persamaan regresi diatas mempunyai arti bahwa baik variabel kemampuan manajemen $\left(X_{1}\right)$, strategi $\operatorname{bisnis}\left(X_{2}\right)$ dan orientasi pasar $\left(X_{3}\right)$ masingmasing memberikan pengaruh positif terhadap kinerja keuangan( $\mathrm{Y})$. Dengan demikian hipotesis yang menyatakan

Tabel 1. Hasil Regresi Berganda

\begin{tabular}{|c|c|c|c|c|c|c|c|c|}
\hline & \multirow[t]{2}{*}{ MODEL } & \multicolumn{2}{|c|}{$\begin{array}{c}\text { Unstandardized } \\
\text { Coefficients }\end{array}$} & \multirow{2}{*}{$\begin{array}{c}\text { Standardized } \\
\text { Coefficients }\end{array}$} & \multirow[t]{2}{*}{$\mathrm{t}$} & \multirow[t]{2}{*}{ Sig. } & \multicolumn{2}{|c|}{ Collinearity Statistics } \\
\hline & & B & Std. Error & & & & Tolerance & VIF \\
\hline \multirow{4}{*}{1} & (Constant) & $-1,818$ & 0,547 & & $-3,320$ & 0,001 & & \\
\hline & $\mathrm{X} 1$ & 0,256 & 0,118 & 0,166 & 2,171 & 0,032 & 0,790 & 1,265 \\
\hline & $\mathrm{X} 2$ & 0,368 & 0,144 & 0,213 & 2,552 & 0,012 & 0,657 & 1,521 \\
\hline & $\mathrm{x} 3$ & 0,734 & 0,118 & 0,517 & 6,202 & 0,000 & 0,662 & 1,511 \\
\hline & $\mathrm{R}$ & \multicolumn{2}{|c|}{0,747} & & & & & \\
\hline & R Square & \multicolumn{2}{|c|}{0,558} & & & & & \\
\hline & Adjusted R Square & \multicolumn{2}{|c|}{0,545} & & & & & \\
\hline
\end{tabular}


kemampuan manajemen $\left(X_{1}\right)$ memiliki pengaruh yang signifikan terhadap kinerja keuangan diterima karena nilai probabilitasnya $0,032<0,05$.

Hipotesis kedua strategi $\operatorname{bisnis}\left(\mathrm{X}_{2}\right)$ mempunyai pengaruh signifikan terhadap kinerja keuangan diterima dengan nilai signifikansi sebesar 0,012<0,05 dan hipotesis terakhir juga menunjukkan penerimaan hipotesis bahwa variabel orientasi pasar $\left(X_{3}\right)$ memiliki pengaruh terhadap kinerja keuangan dengan nilai signifikan sebesar $0,000<0,05$.

Dari hasil pengujian diketahui bahwa secara bersama-sama variabel kemampuan manajemen $\left(X_{1}\right)$, strategi bisnis $\left(X_{2}\right)$ dan orientasi pasar $\left(X_{3}\right)$ memiliki nilai koefisien determinasi $\left(R^{2}\right)$ sebesar 0,545 yang berarti bahwa variabel kemampuan manajemen $\left(X_{1}\right)$, strategi bisnis $\left(X_{2}\right)$ dan orientasi $\operatorname{pasar}\left(X_{3}\right)$ mampu menjelaskan perubahan pada variabel kinerja keuangan ( $\mathrm{Y}$ ) sebesar $54,5 \%$ dan sisanya sebesar $45,5 \%$ dijelaskan oleh variabel lain yang tidak terdefinisi pada penelitian ini.

Kemampuan manajemen memiliki nilai koefisien korelasi sebesar 0,216. Menunjukkan adanya korelasi antara kemampuan manajemen terhadap kinerja keuangan dengan nilai koefisien determinasi sebesar 0,046656 yang berarti bahwa variabel kemampuan manajemen hanya mampu menjelaskan perubahan yang terjadi pada variabel kinerja keuangan sebesar $5 \%$. Selebihnya dijelaskan oleh variabel lain yang tidak terdefinisi dalam penelitian ini.

Kemampuan manajemen pengrajin UMKM Tenun Troso dapat mempengaruhi hasil kerja karyawannya dalam memproduksi kain yang sesuai dengan permintaan pelanggan. Hal ini merupakan salah satu kunci dalam menjalankan usaha dengan tujuan agar usaha yang dirintis tidak kalah dengan usaha lain yang menjadi pesaing. Selain itu dengan memiliki kemampuan manajemen pengrajin dapat meningkatkan efektivitas dan efisiensi waktu dan biaya sehingga dapat meningkatkan laba perusahaan yang menjadi indikator dari kinerja keuangan. Dengan peningkatan laba tersebut maka pengrajin dapat membeli aset dalam mendukung perkembangan usaha menjadi lebih besar.

Pengaruh strategi bisnis terhadap kinerja keuangan memiliki nilai koefisien korelasi yang tidak jauh berbeda dengan variabel kemampuan manajemen, dimana koefisien korelasi strategi bisnis terhadap kinerja keuangan sebesar 0,252, berarti nilai koefisien determinasi untuk variabel strategi bisnis 0,063504. Angka 6\% menunjukkan bahwa variabel strategi bisnis memiliki pengaruh yang minim terhadap peningkatan kinerja keuangan dan selebihnya dijelaskan oleh variabel lain yang tidak diteliti pada penelitian ini.

Strategi bisnis yang baik merupakan jalan untuk mencapai keunggulan bersaing. Keunggulan bersaing yang dimiliki oleh pengrajin UMKM Tenun Troso dicapai dengan selalu menciptakan produk yang berbeda yang sesuai dengan ciri khas tenun Troso di mana pengrajin berusaha membuat corak yang baru dan berbeda dengan pesaing, baik sesam pengrajin tenun maupun dengan pembatik yang ada didaerah lain. Dengan memiliki keunggulan bersaing perusahaan akan tetap dapat berkembang dan meningkatkan nilai perusahaan sebagaiman penelitian (Shaferi \& Handayani 
2013) yang meneliti tentang Keputusan Pendanaan dan Strategi Bisnis Bersaing Untuk Mendorong Peningkatan Nilai Perusahaan ( Studi Pada UMKM Kabupaten BANYUMAS) di mana strategi bisnis memiliki pengaruh positif dan signifikan terhadap nilai perusahaan. Selain itu penelitian (Chen \& Jermias 2014) yang menyatakan bahwa strategi bisnis dang struktur kompensasi yang tepat berpengaruh positif terhadap kinerja perusahaan.

Orientasi pasar memiliki nilai koefisien korelasi sebesar 0.535. Hal ini menunjukkan adanya korelasi yang cukup kuat terhadap kinerja keuangan. Besarnya nilai koefisien determinasi adalah 0.286225 yang berarti bahwa variabel orientasi pasar mampu menjelaskan perubahan yang terjadi pada variabel kinerja keuangan sebesar $29 \%$ dan sisanya dijelaskan oleh variabel lain yang dapat mempengaruhi kinerja keuangan.

Hasil penelitian ini membuktikan bahwa pengrajin Tenun Troso memiliki kemauan untuk memahami para pelanggannnya, memiliki kemauan untuk memonitor para pesaingnya guna mengetahui kain tenun apa yang paling laku dijual oleh pesaingnya dan berusaha mencari informasi tentang kondisi pasar setiap saat guna meningkatkan penjualan. Dengan memperhatikan hal tersebut pengrajin tenun Troso dapat selalu meningkatkan penjualan kain pada pasar sasaran guna peningkatan profit dan peningkatan Aset.

\section{SIMPULAN}

Berdasarkan hasil penelitian serta pembahasan pada penelitian ini dapat disimpulkan bahwa kemampuan manajemen, strategi bisnis dan orientasi pasar memilih pengaruh positif dan signifikan terhadap kinerja keuangan pada UMKM Tenun Ikat Troso Jepara.

Peneliti memberikan saran kepada pengusaha UMKM Tenun Ikat Troso Jepara terutama pada faktor orientasi pasar dan strategi bisnis dalam peningkatan kinerja keuangan, dimana pengusaha UMKM Tenun Ikat Troso Jepara perlu mempertimbangkan untuk menambah produk baru dengan ide yang baru, pengoptimalan fasilitas produksi sehingga dapat memenuhi kebutuhan pelanggan dalam upaya pengembangan segmentasi pasar yang akan memberikan dampak peningkatan penjualan sehingga kinerja keuangan pengusaha UMKM Tenun Ikat Troso Jepara semakin bagus.

Untuk peneliti selanjutnya hendaknya menambah obyek penelitian selain pengusaha UMKM Tenun Ikat Troso dan menambah jumlah variabel yang diteliti dimana mendapat prosentase $45,5 \%$ yang memiliki kemungkinan berpengaruh terhadap peningkatan kinerja keuangan.

\section{DAFTAR PUSTAKA}

Adinoto. (2013). Pengaruh Orientasi Pasar dan Perilaku Kewirausahaan terhadap Kepekaan Perusahaan dan Implikasinya pada Kinerja Perusahaan. Ultima Management.

Akhiri, A. \& Diponegoro, U. (2016). Mencapai Keunggulan Bersaing Melalui Orientasi Pasar Dan Orientasi Kewirausahaan dalam Rangka Meningkatkan Kinerja Bisnis Studi Pada UKM Pengolahan Tepung Tapioka di Ngemplak Kidul Margoyoso Kabupaten Pati.

Chen, Y. \& Jermias, J. (2014). Business strategy, executive compensation and 
firm performance. Accounting \& Finance, 54(1), 113-134.

Ghozali, I. (2006). Aplikasi Analisis Multivariate dengan program SPSS. Semarang: Badan Penerbit Universitas Diponegoro.

Ghozali, I. (2013). Aplikasi Analisis Multivariate dengan Program IBM SPSS 21 Update PLS Regresi. 7 penyunt. Semarang: Badan Penerbit Universitas Diponegoro.

Hunger, J. D. \& Wheelen, T. L. (2003). Manajemen Strategis. Yogyakarta: ANDI.

Irawati, R. (2012). Pengaruh Kemampuan Manajerial dan Motivasi terhadap Kinerja Pewirausaha Kecil/Mikro melalui Kepuasan Kerja. Iqtishoduna Jurnal Ekonomi dan Bisnis Islam, 8(2), 1-21.

Jauch, L. R. \& Glueck, W. F. (1988). Manajemen Strategis dan Kebijakan Perusahaan. Jakarta: Erlangga.

Kementerian Koperasi dan UMKM RI, 2013. http://www.depkop.go.id/beritainformasi/data-informasi/data-umkm/. [Online] Available at: http://www. depkop.go.id/berita-informasi/datainformasi/data-umkm/

Pearce, I. J. (2007). Strategic Management Formulation, Implementation and Control. Singapore: McGraw-Hill.

Rudianto. (2009). Penganggaran; Konsep dan Teknik Penyusunan Anggaran. Jakarta: Erlangga.
Samryn, L. M. (2012). Akuntansi Manajemen; Informasi Biaya untuk Mengendalikan Aktivitas Operasi \& Investasi. Jakarta: Kencana Prenamedia Group.

Shaferi, I. \& Handayani, S.R. (2013). Keputusan Pendanaan Dan Strategi Bisnis Bersainguntuk Mendorong Peningkatkan Nilai Perusahaan(Studi Pada Umkm Kabupaten Banyumas). Sustainable Competitive Advantage (SCA), 3(1).

Silkoset, R. \& Ragnhild. (2009). Market orientation capabilities: a study of learning processes in market-oriented companies, VDM Verlag.

Sinaga, P. (2015). Balanced Scorecard Sebagai Pengukuran Kinerja Koperasi Dan Ukm, Apa Mungkin? INFOKOP, 12(25).

Sugiyono. (2010). Metode Penelitian Bisnis (Pendekatan Kuantitatif, Kualitatif dan $R \& D)$. Bandung: Alfabeta.

Suci, R.P. (2009). Peningkatan Kinerja Melalui Orientasi Kewirausahaan, Kemampuan Manajemen, dan Strategi Bisnis (Studi pada Industri Kecil Menengah Bordir di Jawa Timur). Jurnal Manajemen dan Kewirausahaan, 11(1).

Uncles, M. (2000). Market Orientation. Australian Journal of Management, 25(2), i-ix. 